\title{
Penerapan Model Pembelajaran Koperatif Tipe Team Asisted Individualization (TAI) untuk Meningkatkan Aktivitas dan Hasil Belajar Sejarah Indonesia Siswa
}

\section{Nyoman Nilon*}

SMK Negeri 1 Sukasada, Singaraja, Indonesia

\begin{abstract}
Abstrak
Penelitian ini bertujuan untuk mengetahui (1) peningkatan aktivitas belajar siswa, (2) peningkatan hasil belajar siswa dan (3) respon siswa terhadap penerapan model kooperatif tipe Team Asisted Individualization (TAI) pada mata pelajaran Sejarah Indonesia kelas X Perhotelan I SMK Negeri 1 Sukasada. Jenis penelitian ini penelitian tindakan kelas, dilaksankan dalam dua siklus, setiap siklus terdiri dari perencanaan, pelaksanaan tindakan, observasi atau evaluasi dan refleksi. Subjek penelitian yang digunakan dalam penelitian ini, siswa kelas X Perhotelan I SMK

Keywords:

model pembelajaran tipe Team Asisted Individualization (TAI), aktivitas, hasil belajar, kompetensi pedagogik guru Negeri 1 Sukasada yang berjumlah 35 orang. Objek penelitian (1) aktivitas belajar siswa, (2) hasil belajar siswa, (3) respon siswa. Data aktivitas siswa dikumpulkan dengan metode observasi. Data hasil belajar diperoleh dengan tes hasil belajar dan tes unjuk kerja. Data respon siswa dikumpulkan dengan menggunakan angket tertutup. Analisis data dilakukan secara deskriptif kuantitatif. Hasil penelitian menunjukkan bahwa (1) penerapan model pembelajaran kooperatif tipe Team Asisted Individualization (TAI) dapat meningkatkan aktivitas belajar siswa, yaitu siklus I diperoleh rata-rata aktivitas sebesar 64 dengan kategori cukup aktif, dan pada siklus II diperoleh rata-rata aktivitas sebesar 81 dengan kategori aktif, (2) penerapan model pembelajaran kooperatif tipe Team Asisted Individualization (TAI) dapat meningkatkan hasil belajar siswa, yaitu siklus I pencapaian nilai rata-rata kelas sebesar 69 dengan kategori baik dan pada siklus II diperoleh rata-rata kelas 83 dengan kategori baik, peningkatan hasil telah memenuhi klasifikasi KKM yang ditetapkan 70, (3) respon siswa terhadap penerapan model pembelajaran kooperatif tipe Team Asisted Individualization (TAI) diperoleh ratarata respon sebesar 90 dengan kualifikasi setuju.
\end{abstract}

\section{PENDAHULUAN}

Tantangan berat bangsa Indonesia saat ini adalah menyiapkan sumberdaya manusia yang baik. Dengan bermodalkan sumberdaya manusia yang baik bangsa Indonesia akan mampu bersaing pada zaman global saat ini. Peningkatan pertumbuhan daya saing Bangsa Indonesia yang sangat memprihatinkan merupakan kenyataan rendahnya kualitas sumberdaya manusia Indonesia. Hal ini merupakan tantangan bagi bangsa Indonesia untuk meningkatkan mutu sumber daya manusia Indonesia, dengan menempatkan pendidikan sebagai salah satu wadah dalam pembangunan sumberdaya manusia Indonesia yang cerdas, unggul, dan berdaya saing tinggi. Hanya dengan pendidikan yang bermutu dapat menghasilkan sumberdaya manusia yang berkualitas dan memiliki daya saing tinggi.

Kualitas sumber daya manusia berkaitan erat dengan dunia pendidikan. Dewasa ini perhatian masyarakat lebih tertuju pada pendidikan sebagai penentu kualitas sumber daya manusia dalam bidang

* Corresponding author.

E-mail Addresses: - nilon.nyoman@gmail.com (Nyoman Nilon) 
teknologi. Perkembangan ilmu pengetahuan dan teknologi (Iptek) yang sangat pesat telah banyak membawa perubahan pada semua aspek kehidupan manusia. Perubahan tersebut di satu sisi memberikan manfaat bagi manusia itu sendiri dan di sisi lain dapat memberikan dampak yang negatif sebagai akibat dari kemajuan teknologi. Dengan adanya kemajuan di bidang Iptek ini, maka secara tidak langsung akan terjadi kompetisi dalam segala hal. Hal tersebut menuntut adanya kemampuan sumber daya manusia (SDM) yang berkualitas.

Peran guru dalam pembelajaran, yaitu membuat desain instruksional, menyelenggarakan kegiatan belajar mengajar, bertindak mengajar atau membelajarkan dan mengevaluasi hasil belajar yang berupa dampak pengiring pengajaran. Sedangkan peran siswa adalah bertindak belajar dan menggunakan hasil belajar yang digolongkan sebagai dampak pengiring. Tugas dan fungsi guru hanya memberikan pengetahuan, melainkan juga mencarikan siswa untuk memecahkan persoalan. Oleh karena itu dalam kinerja guru mengelola proses pembelajaran guru harus memiliki strategi, agar siswa dapat belajar secara efektif dan efisien, mengenai pada tujuan yang diharapkan.

Guru dituntut memiliki kinerja yang mampu memberikan dan merealisasikan harapan dan keinginan semua pihak terutama masyarakat umum yang telah mempercayai sekolah dan guru dalam membina anak didik. Dalam meraih mutu pendidikan yang baik sangat dipengaruhi oleh kinerja guru dalam melaksanakan tugasnya sehingga kinerja guru menjadi tuntutan penting untuk mencapai keberhasilan pendidikan. Secara umum mutu pendidikan yang baik menjadi tolok ukur bagi keberhasilan kinerja yang ditunjukkan guru.

Pendidikan adalah suatu interaksi manusia antara pendidik atau guru dengan anak didik atau siswa yang dapat menunjang pengembangan manusia seutuhnya yang berorientasi pada nilai-nilai dan pelestarian serta pengembangan kebudayaan yang berhubungan dengan usaha-usaha pengembangan manusia tersebut. Pendidikan dipandang sebagai salah satu faktor utama yang menentukan pertumbuhan ekonomi, yaitu melalui peningkatan produktivitas tenaga kerja terdidik, dan juga pendidikan dipandang mempunyai peranan penting dalam menjamin perkembangan dan kelangsungan bangsa. Kualitas pendidikan dapat diketahui dari dua hal, yaitu kualitas proses dan produk (Sudjana, 2004: 35).

Fenomena di lapangan menunjukkan bahwa proses pembelajaran di SMK mengalami kecenderungan yang kontra produktif dengan harapan di atas. Hal ini dapat dilihat pada beberapa penelitian tentang proses pembelajaran di SMK (Roestiyah, 2001) yang menggambarkan bahwa proses tersebut berlangsung secara monoton atau tidak ada variasi, berpusat pada guru, dan kurang melibatkan peran aktif peserta diklat. Studi tersebut sesuai dengan pandangan (Sagala,2012) yang menyatakan bahwa kenyataannya pembelajaran di SMK masih mengedepankan tatap muka di ruang kelas. Bahkan, tidak sedikit peserta didik di sejumlah SMK baik teknologi maupun industri yang tidak diberi pelajaran praktek sesungguhnya. Kondisi ini tentunya akan berdampak pada hasil belajar siswa yang cenderung kurang maksimal, sebagaimana yang diungkapkan pada beberapa penelitian.

Permasalahan umum yang saat ini masih menimpa dunia pendidikan kita juga terjadi dalam penyelenggaraan pendidikan yang dialami SMKN 1 Sukasada, yaitu kemampuan guru dalam mengajar masih sangat rendah. Maka untuk mengatasi dan mengantisipasi rendahnya mutu pendidikan salah satu cara yang dapat dilakukan adalah dengan meningkatkan kualitas pelayanan pendidikan. Untuk meningkatkan pelayanan pendidikan pada tingkat instruksional harus dimulai dari peningkatan kualitas layanan yang secara operasional dilaksanakan oleh guru

Berdasarkan hasil pengamatan di kelas X Perhotelan I dalam pembelajaran ditemukan beberapa permasalahan, sebagai berikut. Pertama, aktivitas belajar kurang baik, ditunjukkan pada saat guru menjelaskan siswa tidak mendengarkan dan beberapa orang siswa suka bercanda dengan temannya, berbicara sesama teman duduknya. Pada saat guru memberikan pertanyaan siswa tidak ada yang mengacungkan tangan untuk menjawab pertanyaan. Kedua, hasil belajar siswa banyak yang belum mencapai skor nilai yang ditetapkan minimal 70. Ketiga, metode mengajar masih menoton, hanya menggunakan metode ceramah walaupun kurikulum menuntut metode yang lebih inovatif, sehingga siswa tidak aktif, interaksi antar siswa dan interaksi siswa dengan guru tidak ada.

Permasalahan seperti inilah yang perlu diperhatikan oleh setiap guru. Guru harus dapat menerapkan berbagai variasi metode berkelompok yang sesuai dengan keadaan kelas dan siswanya. Keberhasilan suatu proses pembelajaran dapat diukur dari keberhasilan siswa mengikuti pembelajaran tersebut. Sedangkan hasil belajar yang baik harus didukung oleh pembelajaran yang berkualitas yakni pembelajaran yang mampu menumbuhkan motivasi. Pembelajaran akan lebih optimal jika pendekatan atau model yang digunakan tepat. Model pembelajaran seperti ini meniadakan persaingan individu, menumbuhkan sikap demokratis dan melatih kemampuan memecahkan suatu tugas yang diberikan. Alternatif yang dapat dipilih untuk membuat pelajaran Sejarah Indonesia lebih menarik dan menyenangkan, dapat meningkatkan keaktifan siswa serta pelajaran Sejarah Indonesia lebih mudah dipahami, guru dapat menerapkan dan mengembangakan model pembelajaran Kooperatif Tipe Team 
Asisted Individualization (TAI) untuk pembelajaran Sejarah Indonesia pada materi di sekolah, selain menggunakan model pembelajaran yang sudah ada di Kurikulum 13.

Model pembelajaran TAI ini dikembangkan oleh Slavin. Model pembelajaran kooperatif menuntut siswa untuk menggali pengetahuan dan pembelajaran individu. Solusi ini dipandang cocok untuk menanggulangi permasalahan rendahnya hasil belajar dan aktivitas belajar siswa, mengingat metode pemberian tugas kepada siswa sehingga akan timbul rasa ingin tahu dan termotivasi untuk mencari atau menemukan solusi dari permasalahan yang diberikan. Disamping itu juga siswa merasa bertanggung jawab baik secara individu maupun kelompok.

Peran guru hanya memfasilitasi siswa dalam membuat rangkuman, mengarahkan dan memberikan penegasan pada materi pembelajaran yang telah dipelajari. Oleh karena itu, untuk mengatasi kesulitan belajar siswa secara individual, peneliti akan menerapkan metode pembelajaran kooperatif TAI pada mata pelajaran sejarah Indonesia. Keunggulan pembelajaran kooperatif tipe TAI menurut Slavin (1995), menyatakan keunggulan, diantaranya, a) Memberikan siswa untuk membangun pengetahuan, b) berpartisipasi aktif dalam kelompok, c) efektif untuk kemampuan siswa yang beragam, d) Siswa tidak hanya menguasai materi saja tetapi mengetahui keterampilan siswa yang lainnya

Menurut Slavin, sukses "individual" dan sukses "kelompok" merupakan pembelajaran yang digunakan pada mata pelajaran Matematika, hasil belajar siswa juga semakin meningkat pada mata pelajaran Matematika karena siswa termotivasi untuk belajar materi yang diberikan oleh guru (Shalomo,28:2009). Keunggulan pembelajaran kooperatif tipe TAI yang diberikan pada siswa kelas X Perhotelan I, memberikan peluang kepada siswa yang lebih pintar bisa menjelaskan materi kepada temannya, siswa bekerjasama dengan temannya, sehingga siswa melaksanakan materi yang dipelajari dengan baik. Selain itu pembelajaran dengan tipe Team Assisted Individualization (TAI) juga sangat efektif dan efesien, karena kelas sudah dibagi ke dalam kelompok dan bertanggung jawab dengan materi yang diberikan.

Berdasarkan pemaparan di atas, maka peneliti mencoba menerapkan pada mata pelajaran Sejarah Indonesia siswa kelas X Perhotelan I SMK Negeri 1 Sukasada, dimana tampak bahwa model pembelajaran Kooperatif Tipe Team Assisted Individualization (TAI) mempengaruhi aktivitas dan hasil belajar siswa. Oleh sebab itu, penulis mengajukan penelitian tindakan kelas yang berjudul "Penerapan Model Pembelajaran Kooperatif Tipe Team Asisted Individualization (TAI) Untuk Meningkatkan Aktivitas dan Hasil Belajar Sejarah Indonesia Siswa Kelas X Perhotelan I SMK Negeri 1 Sukasada Semester Ganjil Tahun Pelajaran 2018/2019"

Tujuan dari penelitian ini adalah (1) Untuk mengetahui peningkatan aktivitas belajar siswa pada mata pelajaran Sejarah Indonesia melalui penerapan model pembelajaran kooperatif tipe Team Assisted Individualization (TAI), 2) Untuk mengetahui peningkatan hasil belajar siswa pada mata pelajaran Sejarah Indonesia melalui penerapan model pembelajaran kooperatif tipe Team Assisted Individualization (TAI), 3) Untuk mengetahui respon siswa dalam penerapan model pembelajaran kooperatif tipe Team Assisted Individualization (TAI) pada mata pelajaran Sejarah Indonesia siswa kelas X Perhotelan I SMK Negeri 1 Sukasada.

\section{METODE PENELITIAN}

Jenis penelitian ini termasuk penelitian tindakan kelas (classroom action research). Penelitian tindakan kelas dilakukan untuk memecahkan masalah pemebelajaran di kelas, meningkatkan efektifitas metode mengajar, pemberian tugas kepada siswa, penilaian siswa dan lain sebagainya (Arikunto, 2011: 13). Penelitian ini dilaksanakan pada semester ganjil tahun pelajaran $2018 / 2019$ bertempat di SMK Negeri 1 Sukasada Jurusan Perhotelan, yang beralamat di Jalan Srikandi, Sambangan, Sukasada, Kabupaten Buleleng. Subyek penelitian ini adalah siswa kelas X Perhotelan I SMK Negeri 1 Sukasada, dengan jumlah siswa 35 orang. Objek dalam penelitian ini 1) Aktivitas belajar siswa dalam penerapan model pembelajaran Team Assisted Individualization (TAI) pada mata pelajaran Sejarah Indonesia, 2) Hasil belajar siswa dalam penerapan model pembelajaran Team Assisted Individualization (TAI) pada mata pelajaran Sejarah Indonesia, 3) Respon siswa dalam penerapan model pembelajaran Team Assisted Individualization (TAI) pada mata pelajaran Sejarah Indonesia.

Rancangan penelitian ini menggunakan model Lewin, Kemmis dan Me Taggart. Penelitian ini dilaksanakan dalam dua siklus dengan masing-masing siklus terdiri dari empat tahapan yang terdiri dari empat komponen, yaitu (1) perencanaan, (2) tindakan, (3) observasi atau evaluasi, (4) refleksi (Arikunto, 2011: 93) 


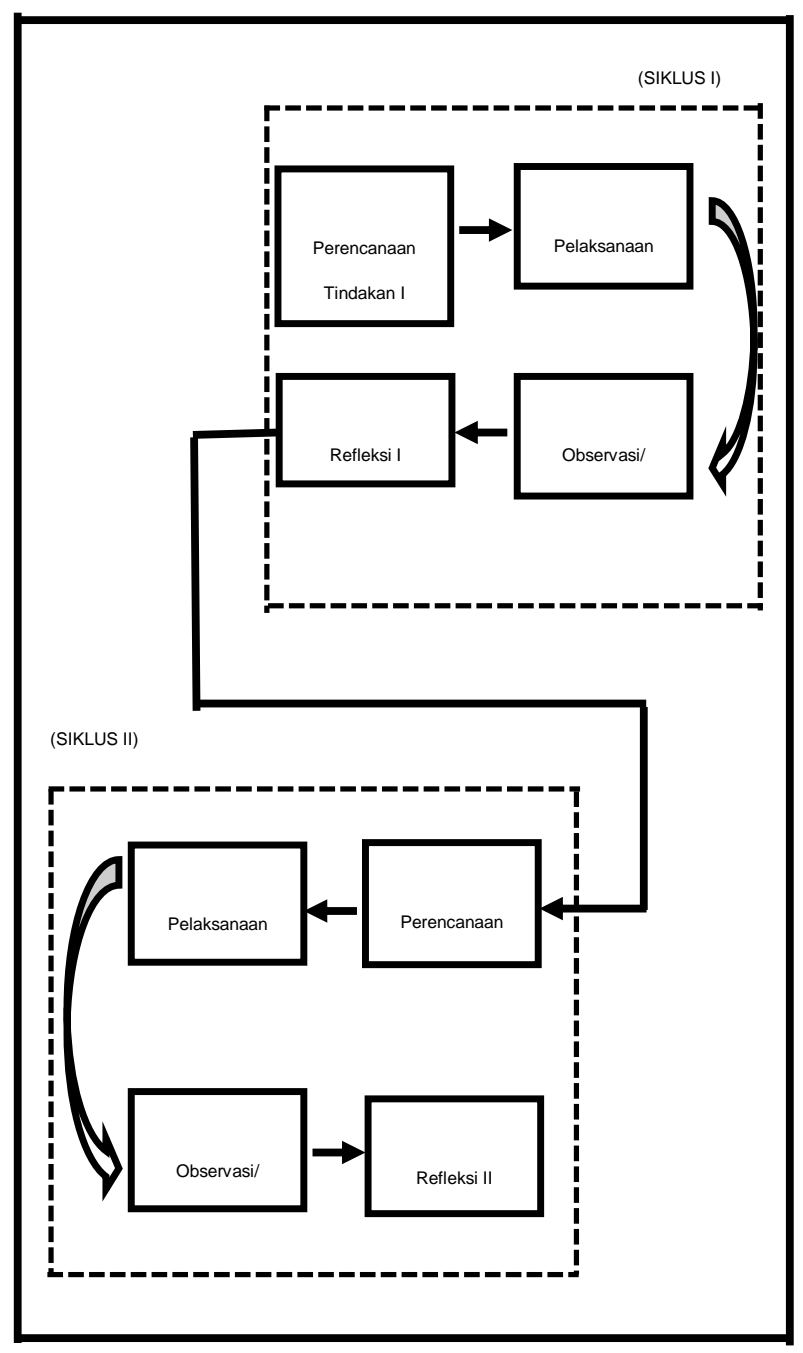

Gambar 1. Rancangan Penelitian

Berdasarkan variable-variabel yang menjadi objek penelitian ini, maka jenis data dan instrumen yang digunakan untuk mengumpulkan data yang diperlukan dalam penelitian ini, yaitu 1) Aktivitas belajar siswa dikumpulkan dengan teknik observasi instrumen yang digunakan adalah lembar pengamatan atau lembar observasi. Penilaian dilakukan terhadap masing-masing aspek aktivitas dan kerja kelompok di dalam kelas, yaitu. a) interaksi dengan guru, b) interaksi siswa dengan siswa, c) kerjasama kelompok, d) partisipasi dalam kegiatan pembelajaran. Semua aspek aktivitas di atas diobservasi selama proses pembelajaran berlangsung dengan mencatat jumlah individu dalam kelompok yang melakukan aktivitas tersebut, 2) Hasil belajar siswa diambil pada setiap akhir siklus yang diberikan. Teknik pengumpulan data dengan cara memberikan tes akhir, 3) Respon siswa dilaksanakan satu kali diambil pada akhir siklus II setelah tes akhir siklus II. Teknik pengumpulan data dengan cara memberikan angket.

Teknik analisis data, 1) aktivitas belajar siswa dianalisis dengan statistik deskriptif. Berdasarkan skor rata-rata (M), mean ideal (MI), dan standar deviasi ideal (SDI), Untuk mengkategorikan skor aktivitas belajar siswa digunakan lima kategori berdasarkan penilaian acuan patokan (PAP). Konversi dengan PAP dapat dilakukan dengan menghitung mean dan SD ideal (Candiasa, 2010: 45), 2) Hasil belajar siswa dianalisis secara deskriptif kuantitatif kemudian dipaparkan secara kualitatif. Sedangkan kualifikasi hasil belajar siswa dikatakan berhasil apabila pada kategori baik, yang diperoleh berdasarkan pedoman konversi skor yang terdapat pada kurikulum SMK Negeri 1 Sukasada tahun pelajaran 2018/2019, 3) Respon siswa Data respon siswa akan dianalisis skala likert digunakan untuk mengukur sikap, pendapat dan persepsi seseorang atau sekelompok tentang kejadian atau gejala sosial (Trianti, 2009: 242) 


\section{ANALISIS DAN PEMBAHASAN}

Dari hasil pengamatan yang dilakukan pada saat siswa berdiskusi secara kelompok dengan menggunakan instrumen observasi dengan 18 diskriptor, skor tertinggi 90 dan skor terendah adalah 18. Data yang diperoleh dengan menjumlahkan skor masing-masing indikator aktivitas siswa, hasil aktivitas belajar siswa dengan kategori sangat aktif tidak ada (0\%), kategori aktif 16 orang $(45,71 \%)$, cukup aktif 19 orang $(54,29 \%)$, kategori kurang aktif dangan sangat kurang aktif tidak ada (0\%). Jadi rata-rata skor aktivitas belajar siswa pada siklus I adalah 64 termasuk dalam kategori cukup aktif.

Data hasil belajar siswa diperoleh dari hasil tes yang dilaksanakan pada akhir siklus I, skor hasil tes belajar siklus I adalah siswa kategori sangat baik 4 orang $(11,43 \%)$, kategori baik 13 orang $(37,14 \%)$, kategori cukup 10 orang $(28,57 \%)$, kategori kurang 8 orang $(22,86 \%)$, hasil ini menunjukkan rata-rata sebesar 69 dengan banyaknya siswa yang tuntas sebanyak 27 orang dengan ketuntasan klasikal 77\% dengan kategori kurang. Skor yang sudah didapatkan pada siklus I belum sesuai dengan kriteria keberhasilan yang ditetapkan. Hasil belajar siswa dikategorikan berhasil apabila berada pada kriteria baik. Sedangkan tuntutan penelitian ini dikatakan berhasil apabila ketuntasan klasikalnya mencapai > 70\%. Masih terdapat beberapa orang siswa yang belum mencapai standar Kriteria Ketuntasan Maksimal (KKM) SMK Negeri 1 Sukasada untuk mata pelajaran Sejarah Indonesia adalah 70, oleh karena itu untuk mata pelajaran Sejarah Indonesia semua siswa harus mendapatkan kategori baik.

Refleksi siklus I berdasarkan aktivitas belajar siswa pada siklus I selama pemberian tindakan, nilai rata-rata skor aktivitas siswa yang diperoleh sebesar 64 dan berada pada kategori cukup aktif. Adapun faktor yang menyebabkan aktivitas siswa kurang baik karena 1) siswa belum terbiasa dengan pembelajaran kooperatif tipe TAI, 2) siswa kurang yakin dengan kemapuannya, hal ini ditunjukkan dengan sikap kurang percaya diri dalam mengerjakan soal-soal tes, 3) siswa masih pasif dalam mengemukakan pendapat dalam kelompok dan hanya beberapa siswa yang aktif, sehingga proses pelaksanaan pembelajaran dan diskusi kurang bisa membawa siswa untuk aktif berbicara mengemukakan pendapat, bertanya dan menjawab pertanyaan. Hal ini diamati ketika beberapa siswa yang tidak memperhatikan materi pembelajaran yang di diskusikan.

Hasil tindakan yang dilaksankan pada siklus I hasil belajar siswa mendapatkan skor rata-rata kelas yang diperoleh sebesar 69 , siswa yang tuntas sebanyak 27 orang serta ketuntasan klasikalnya diperoleh sebesar 77\%. Rendahnya skor rata-rata yang diperoleh pada siklus I disebabkan oleh beberapa faktor, yaitu. 1) siswa belum memahami materi yang diberikan, 2) siswa kurang disiplin dalam kegiatan pembelajaran, hal ini diamati pada saat siswa diskusi kurang memperhatikan materi yang didiskusikan.

Dari permasalahan siklus I, maka diperlukan beberapa upaya perbaikan pada siklus II. Untuk mengatasi permasalahan tersebut dilakukan beberapa hal, sebagai berikut. 1) Guru meminta siswa untuk lebih disiplin dalam mengikuti pembelajaran di kelas, 2) Guru membangkitkan siswa untuk lebih giat lagi dalam kerjasama kelompok, serta memberikan bimbingan materi yang diberikan untuk dipahami, 3) peneliti membantu tiap anggota kelompok yang mengalami masalah, sehingga terjadi interaksi antara siswa dengan siswa dan antara siswa dengan guru, serta guru aktif dalam menyampaikan pembelajaran di kelas.

Hasil penelitian pada siklus II untuk aktivitas belajar siklus II bahwa aktivitas belajar siswa dalam kategori sangat aktif 9 Orang $(25,71 \%)$ dan aktif 26 orang $(74,29 \%)$, sedangkan cukup aktif, kurang aktif dan sangat kurang aktif tidak ada (0\%), Jadi skor rata-rata aktivitas belajar siswa pada siklus II adalah 81 dengan kategori aktif.

Data hasil belajar siswa diperoleh dari hasil tes hasil belajar yang dilaksanakan pada akhir siklus II, skor hasil belajar siklus II adalah sebagai berikut. siswa dengan kategori sangat baik 8 orang $(22,86 \%)$, baik 27 Orang $(77,14 \%)$. Sedangkan siswa dengan kategori cukup dan kurang tidak ada (0\%). Dari data hasil belajar siswa pada siklus II tes hasil belajar siswa menunjukkan skor rata-rata kelas sebesar 83 dengan banyaknya siswa yang tuntas 35 orang serta ketuntasan klasikal sebesar $100 \%$ dengan kategori baik. Skor rata-rata kelas siswa yang diperoleh pada siklus II telah mencapai Kriteria Ketuntasan Minimal (KKM) 70, sehingga dapat dikatakan pembelajaran sudah sesuai dengan kriteria keberhasilan yang ditetapkan.

Data respon siswa terhadap pembelajaran dasar desain disebarkan melalui angket respon siswa sebanyak 20 pernyataan, siswa yang memberikan respon sangat setuju sebanyak 18 orang $(51,43 \%)$, setuju 12 orang $(34,29 \%)$, kurang setuju 5 orang $(14,29 \%)$, sedangkan untuk tidak setuju dan sangat tidak setuju tidak ada (0\%). Dengan demikian dapat disimpulkan bahwa respon siswa terhadap pembelajaran Sejarah Indonesia pada kategori setuju dengan skor rata-rata 90 data respon siswa pada 
lampiran 8, respon siswa setuju menunjukkan pembelajaran Sejarah Indonesia dengan menggunakan model pembelajaran kooperatif tipe TAI dapat diterima oleh siswa.

Refleksi siklus II, Berdasarkan perbaikan proses pembelajaran pada tindakan siklus I, tampak adanya perubahan peningkatan aktivitas dan hasil belajar siswa. Nilai rata-rata aktivitas belajar pada siklus I skor rata-rata kelas mencapai sebesar 64 dengan kategori cukup aktif, sedangkan pada siklus II skor rata-rata sebesar 81 dengan kategori aktif. Keadaan ini disebabkan oleh 1) pembelajaran kelompok berjalan dengan lancar, adanya kerjasama antar siswa, 2) siswa mampu memahami materi yang diberikan, maka pembelajaran sudah berlangsung efektif.

Untuk hasil belajar siswa nilai rata-rata pada siklus I sebesar 69 dengan banyaknya siswa yang tuntas 27 orang dengan ketuntasan klasikal 77\%, termasuk kategori kurang, sedangkan nilai rata-rata hasil pada siklus II sebesar 83 dengan banyaknya siswa yang tuntas 34 orang dengan ketuntasan klasikal $100 \%$ termasuk kategori baik. Peningkatan ini disebabkan adanya peningkatan dalam pembelajaran berlangsung, sehingga interaksi pembelajaran dapat berjalan dengan optimal. Selama pembelajaran ini menunjukkan adanya kerjasama dalam kelompok lebih efektif.

Respon siswa dilaksanakan setelah pembelajaran siklus II yang digunakan untuk mengetahui tanggapan siswa tentang penggunaan kooperatif tipe TAI terhadap mata pelajaran Sejarah Indonesia pada kategori setuju dengan skor rata-rata 90.

Berdasarkan hasil penelitian yang telah dilaksanakan selama dua siklus, dengan penerapan pembelajaran kooperatif tipe TAI menunjukkan terjadinya peningkatan aktivitas dan hasil belajar siswa.

Hasil analisis data aktivitas siswa pada siklus I skor rata-rata aktivitas sebesar 64 dengan kategori cukup aktif. Hal ini diamati dari data hasil yang tampak, sangat aktif tidak ada (0\%), 16 orang siswa $(45,71 \%)$ dengan kategori aktif, 19 orang siswa $(54,29 \%)$ dengan cukup aktif dan untuk kategori kurang aktif dan sangat kurang aktif tidak ada (0\%). Penyebab aktivitas belajar pada siklus I kurang maksimal diakibatkan oleh beberapa kendala adalah 1) siswa masih sulit berinteraksi dengan anggota kelompoknya, keadaan ini disebabkan karena masing-masing siswa belajar secara individual, 2) siswa kurang disiplin dalam mempersiapkan diri untuk melakukan diskusi, ini diamati ketika beberapa siswa bercanda dan kurang memperhatikan materi yang di bahas. Berdasarkan hasil refleksi pada siklus I, maka pelaksanaan tindakan pada siklus II mengacu pada perbaikan terhadap tindakan yang telah berlangsung pada siklus I. nilai rata-rata aktivitas siswa pada siklus I sebesar 64 dengan kualifikasi cukup aktif, sedangkan untuk siklus II mengalami peningkatan menjadi 81 dengan kualifikasi aktif. Berdasarkan kriteria keberhasilan penelitian untuk aktivitas siswa, dimana penelitian dikatakan berhasil jika nilai aktivitas berada pada kategori aktif. Keberhasilan dalam penelitian ini menguatkan pernyataan Oemar Hamalik (2010: 171), yaitu pembelajaran yang menyediakan kesempatan belajar dan beraktivitas sendiri kepada siswa merupakan dasar untuk mencapai hasil belajar yang lebih optimal.

Berdasarkan analisis nilai rata-rata hasil belajar pada siklus I, yaitu diperoleh skor rata-rata hasil belajar siswa dengan rata-rata 69, banyaknya siswa yang tuntas sebanyak 27 orang dengan ketuntasan klasikal 77\%. Dari hasil tersebut, bahwa pelaksanaan tindakan siklus I belum mencapai keberhasilan, ketidak berhasilan tersebut disebabkan oleh beberapa permasalahan yang terjadi selama pelaksanaan tindakan siklus I, seperti perhatian siswa dalam mengikuti pembelajaran masih kurang, siswa masih bekerja secara individu atau kerja sama dalam kelompok masih kurang untuk menyelesaikan permasalahan yang diberikan oleh guru. Tindakan perbaikan yang dilakukan untuk mengatasi kendala dan permasalahan yang ditemui adalah seperti yang telah dipaparkan pada hasil belajar refleksi siklus I. perbaikan tindakan yang dilakukan adalah sebagai berikut.1) siswa belum terbiasa dengan pembelajaran koopertif tipe TAI, 2) siswa kurang yakin dengan kemampuannya, 3) siswa masih pasif dalam mengemukakan pendapat dalam berkelompok dan hanya beberapa siswa yang aktif, sehingga proses pelaksanaan pembelajaran dan diskusi kurang bisa membawa siswa untuk aktif berbicara mengemukakan pendapat, bertanya dan menjawab pertanyaan, 4) siswa belum memahami materi yang diberikan, 5) siswa kurang disiplin dalam kegiatan pembelajaran. Hal ini diamati ketika beberapa siswa yang tidak memperhatikan materi pembelajaran yang didiskusikan. Berdasarkan perbaikan tindakan siklus I maka pada siklus II diperoleh peningkatan hasil belajar siswa baik itu rata-rata kelas, banyak siswa yang tuntas maupun ketuntasan klasikal. Nilai rata-rata hasil belajar siswa pada siklus II diperoleh sebesar 83, banyak siswa yang tuntas 35 orang dengan ketuntasan klasikal sebesar $100 \%$. Jika dibandingkan dengan hasil belajar pada siklus I maka terjadi peningkatan $12 \%$. Hal ini berarti penerapan pembelajaran kooperatif tipe Team Asisted Individualization untuk meningkatkan aktivitas dan hasil belajar sejarah Indonesia kelas X Perhotelan I SMK Negeri 1 Sukasada efektif untuk diterapkan.

Data respon siswa dilaksanakan setelah tes hasil belajar siklus II yang diperoleh dengan cara menyebarkan angket kepada siwa yang menjadi subyek penelitian. Hasil analisis data respon siswa terhadap pembelajaran kooperatif tipe TAI diperoleh dengan skor rata-rata respon siswa sebesar 90 dengan kualifikasi setuju. Hal ini disebabkan antara kerjasama dalam kelompok dan respon yang 
diberikan oeh siswa beranggapan bahwa model pembelajaran kooperatif tipe TAI sangat menyenangkan, siswa dapat belajar berkelompok. Respon ini mengalami perubahan setelah diadakan penerapan model pembelajarn kooperatif tipe TAI, siswa senang karena dapat lebih aktif untuk mengerjakan tugas yang diberikan sesuai dengan hasil penelitian Sutrisni (2011: 2) yang menyatakan bahwa model pembelajaran kooperatif tipe TAI menyenangkan dalam pembelajaran kelompok kecil saling bekerjasama, respon dikatakan positif apabila hasil dikatakan berhasil.

Keberhasilan peningkatan aktivitas, hasil dan respon pada penerapan model pembelajaran kooperatif tipe TAI, memberikan kesempatan kepada siswa untuk saling berinteraksi dan mengungkapkan pemahaman dan pendapatnya, baik dalam kelompok. Siswa diberikan kesempatan untuk mengkomunikasikan pendapatnya, terutama bagi siswa yang masih malu (pasif), akibatnya mereka menjadi lebih berani untuk mengungkapkan pendapatnya maupun bertanya jika mereka belum mengerti sehingga terjadi interaksi sosial dalam kegiatam pembelajaran.

\section{KESIMPULAN}

Berdasarkan penelitian tindakan kelas yang telah dilaksanakan dengan menggunakan penerapan pembelajaran kooperatif tipe TAI dapat disimpulkan. 1) Penerapan model pembelajaran kooperatif tipe Team Asisted Individualization (TAI) untuk meningkatkan aktivitas belajar Sejarah Indonesia siswa kelas X Perhotelan I SMK Negeri 1 Sukasada, dilihat dari data aktivitas siswa siklus I diperoleh rata-rata aktivitas sebesar 64 berada pada kategori cukup aktif dan pada siklus II diperoleh rata-rata aktivitas sebesar 81 berada pada kategori aktif. Pencapaian rata-rata aktivitas siswa pada siklus I mengalami peningkatan rata-rata aktivitas pada siklus II, 2) Penerapan model pembelajaran kooperatif tipe Team Asisted Individualization (TAI) untuk meningkatkan hasil belajar Sejarah Indonesia siswa kelas X Perhotelan I SMK Negeri 1 Sukasada, dapat dilihat dari pencapaian rata-rata hasil belajar siklus I sebesar 69 dengan kategori kurang dan pada siklus II mengalami peningkatan rata-rata hasil belajar siswa sebesar 83 dengan kategori baik, 3) Respon siswa terhadap penerapan model pembelajaran kooperatif tipe Team Asisted Individualization (TAI) untuk meningkatkan hasil belajar Sejarah Indonesia siswa kelas X Perhotelan I SMK Negeri 1 Sukasada, yang dilaksanakan pada siklus II mencapai rata-rata respon siswa sebesar 90 berada pada kualifikasi setuju.

Berdasarkan simpulan di atas, maka saran yang dapat diajukan adalah sebagai berikut. 1) Bagi siswa disarankan kepada siswa agar selalu aktif dalam pembelajaran di kelas sehinga hasil belajar menjadi lebih baik, 2) Bagi guru Guru normatif, adaptif maupun produktif di SMK, hendaknya mencoba menggunakan model pembelajaran kooperatif tipe Team Asisted Individualization (TAI), sebagai alternatif untuk meningkatkan aktivitas dan hasil belajar siswa pada setiap bidang pelajaran, 3) Bagi sekolah disarankan untuk sekolah dapat dijadikan sebagai acuan dalam pembelajaran di semua bidang mata pelajaran, karena dapat meningkatkan mutu dan kualitas Pendidikan, 4) Bagi peneliti lainnya disarankan kepada peneliti lainnya yang berkaitan dengan pembelajaran produktif di SMK untuk mencoba melaksanakan kooperatif tipe Team Asisted Individualization (TAI) dalam waktu yang lebih lama, sehingga akan lebih nampak aktivitas dan hasil belajar siswa.

\section{DAFTAR PUSTAKA}

Anwar, K., \& Harmi, H. (2011). Perencanaan Sistem Pembelajaran Kurikulu Tingkat Satuan Pendidikan (KTSP). Bandung: Alfabeta.

Arikunto, Suharsimi. 2011. Dasar-dasar Evaluasi Pendidikan (Edisi revisi). Jakarta: Bumi Aksara.

Arikunto, Suharsimi. (2017). Manajemen Peneitian. Jakarta: Rineka Cipta.

Candiasa, I M. 2010. Buku Ajar Statistik Multivariat disertai Aplikasi dengan SPSS. IKIP Negeri Singaraja.

Hamdani. (2011). Strategi Belajar Mengajar. Bandung : Pustaka Setia.

M, R. (2013). Meningkatkan Self-Efficacy Pada Pembelajaran Matematika Melalui Model Kooperatif Tipe Team Assisted Individualization (TAI) Pada Siswa Kelas Viiasmp Negeri 27 Makassar. Jurnal Matematika Dan Pembelajaran (Mapan) , 112. 
Nurzakiaty, Ida. 2015. Penerapan Model Pembelajaran Kooperatif Tipe Team Assisted Individualization (TAI) Dalam Pembelajaran Integral Di Kelas XII IPA-2 SMA Negeri 8 Banda Aceh. Jurnal Peluang, Volume 3, Nomor 2.

Puspitasari, Luki. 2015. Penerapan Model Kooperatif Tipe Team Assisted Individualization (TAI) dalam Peningkatan Pembelajaran IPA Di Kelas V. Kalam Cendekia, Volume 4, Nomor 2.

Ramlan, M. 2013. Meningkatkan Self-Efficacy Pada Pembelajaran Matematika Melalui Model Kooperatif Tipe Team Assisted Individualization (TAI) Pada Siswa Kelas VIIA SMP Negeri 27 Makassar. Jurnal Matematika Dan Pembelajaran (MAPAN), VOL. 1 NO. 1.

Roestiyah, N.K. 2001. Strategi Belajar Mengajar. Jakarta: Rineka Cipta.

Sagala. 2012. Konsep dan Makna Pembelajaran. Bandung: Alfabeta.

Sharan, S. (2012). Cooperative Learning. Yogyakarta: Familia.

Slameto. 2003. Belajar dan Faktor-faktor yang Mempengaruhinya. Jakarta: Rineka Cipta.

Sudjana, Nana. 2004. Penilaian Hasil Proses Belajar Mengajar. Bandung: PT. Remaja Rosdakarya.

Sutrisni. 2011. Penerapan Kooperatif Tipe TAI untuk Meningkatkan Aktivitas hasil belajar siswa kelas IX SMK Piri Sleman. Yogyakarta

Suryadi, D. (2011). Pendidikan Matematika. didi-suryadi.staff.upi.edu , 16-18.

Tarim, K., \& Akdeniz, F. (2007). The effects of cooperative learning on Turkish elementary students' Jurnal Ilmiah Sekolah Dasar, Vol. 2, No. 4, Tahun 2018, pp. 412-419 419 Rizky Ratna Wijayanti / Penerapan Model Pembelajaran Cooperative Tipe TAI (Team Assisted Individualization) Untuk Meningkatkan Belajar Dan Kemampuan Berpikir Kritis Matematika mathematics achievement and attitude towards mathematics using TAI and STAD methods. Edu Stud Math .

Tinungki, G. M. (2015). The Role of Cooperative Learning Type Team Assisted Individualization to Improve the Students' Mathematics Communication Ability in the Subject of Probability Theory. IISTE .

Trianti. 2009. Model-model Pembelajaran Inovatif. Bandung: PT Remaja Rosdakarya.

Ujiati, Cahyaningsih. 2018. Penerapan Model Pembelajaran Kooperatif Tipe TAI (Team Assisted Individualization) Untuk Meningkatkan Hasil Belajar Siswa Pada Mata Pelajaran Matematika. Jurnal Cakrawala Pendas Vol. 4 No.1 